\title{
A new genus of microphthalmic Rhytirrhinini from Andean leaf litter (Coleoptera: Curculionidae)
}

ROBERT S. ANDERSON and JUAN J. MORRONE

Ent. scand.

Anderson, R. S. \& Morrone, J. J.: A new genus of microphthalmic Rhytirrhinini from Andean leaf litter (Coleoptera: Curculionidae). Ent. scand. 27: 259-278. Copenhagen, Denmark.

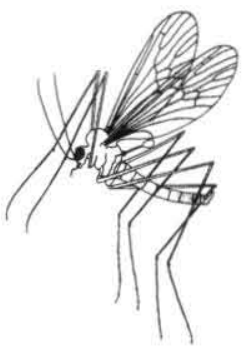
September 1996. ISSN 0013-8711.

The rhytirrhinine genus Andesianellus gen. n. (type species A. microphthalmicus sp. n.), and nine new species, are described from the highlands of Colombia (1), Ecuador (5), and Peru (3). Andesianellus species are characterized by the following combination of character states: very small body size $(<3.5 \mathrm{~mm})$, eyes reduced to 8 or fewer facets, rostrum distinctly tricarinate dorsally, and basal elytral margin raised and subcarinate. Most specimens were collected in berlese funnel samples of various kinds of montane forest leaf litter. The closest relatives are hypothesized to be the Andean genera Adioristidius Voss and Macrostyphlus Kirsch.

R. S. Anderson, Research Division, Canadian Museum of Nature, P.O. Box 3443, Station D, Ottawa, ON. K1P 6P4, Canada.

J. J. Morrone, Laboratorio de Sistemática y Biología Evolutiva (LASBE), Museo de La Plata, Paseo del Bosque, 1900 La Plata, Argentina.

\section{Introduction}

The greatest diversity of the South American Rhytirrhinini occurs in the Subantarctic province of southern Chile and Argentina (Morrone 1992). Recently, Morrone (1994a, b, c) revised the genera Acrorius Kirsch, Nacodius Morrone, Macrostyphylus Kirsch, Adioristidius Voss, and Amathynetoides Morrone, from the Andean region of Venezuela, Colombia, Ecuador, Peru and Bolivia. It is now apparent that another major centre of diversification in this tribe of weevils is within this area, primarily at elevations of $2000 \mathrm{~m}$ and above.

This paper describes a new genus and nine new species of Rhytirrhinini from high elevations in Colombia, Ecuador, and Peru, and discusses their cladistic relationships. All of the species exhibit various degrees of structural modification associated with ground substrate-dwelling habits, which include reduced body size, markedly reduced eye size (to a single facet in 4 species), decreased pigmentation, absence of hind wings, shortened metasternum, and absence of the metepisternal suture. Of other known Rhytirhinini, only some species of Falklandius Enderlein (best exemplified by $F$. chilensis Morrone \& Anderson and $F$. peckorum Morrone \& Anderson) and Lan- teriella micropthalma Morrone show similar structural modifications (Morrone 1992; Morrone \& Anderson 1995).

\section{Material and methods}

Specimens examined in this study were obtained on loan from, and are deposited in the following collections:

AMNH American Museum of Natural History, New York, New York, U.S.A.; Lee Herman.

BMNH The Natural History Museum, London, England; Christopher H.C. Lyal.

CMNC Canadian Museum of Nature, Ottawa, Ontario, Canada; Robert S. Anderson.

CNCI Canadian National Collection of Insects, Biological Resources Division, Agriculture Canada, Ottawa, Ontario, Canada; Donald E. Bright.

CWOB Charles W. O'Brien private collection, Tallahassee, Florida, U.S.A.; Charles W. O'Brien.

FMNH Field Museum of Natural History, Chicago, Illinois, U.S.A.; Alfred F. Newton, Jr.

HAHC Henry and Anne Howden private collection, Ottawa, Ontario, Canada; Anne T. Howden.

MLP Museo de La Plata, La Plata, Argentina; Ricardo Ronderos.

USNM United States National Museum, Washington D.C., U.S.A.; James Pakaluk.

Measurements were made with an ocular micrometer in a stereoscopic microscope; drawings were made with a 
camera lucida attached to it. For type material, exact label data are cited, separate lines are indicated by slashes. Ratio of length to width is abbreviated l:w.

\section{Genus Andesianellus gen. $\mathbf{n}$.}

(Figs 1-55)

Type species: Andesianellus microphthalmicus sp. n., here designated.
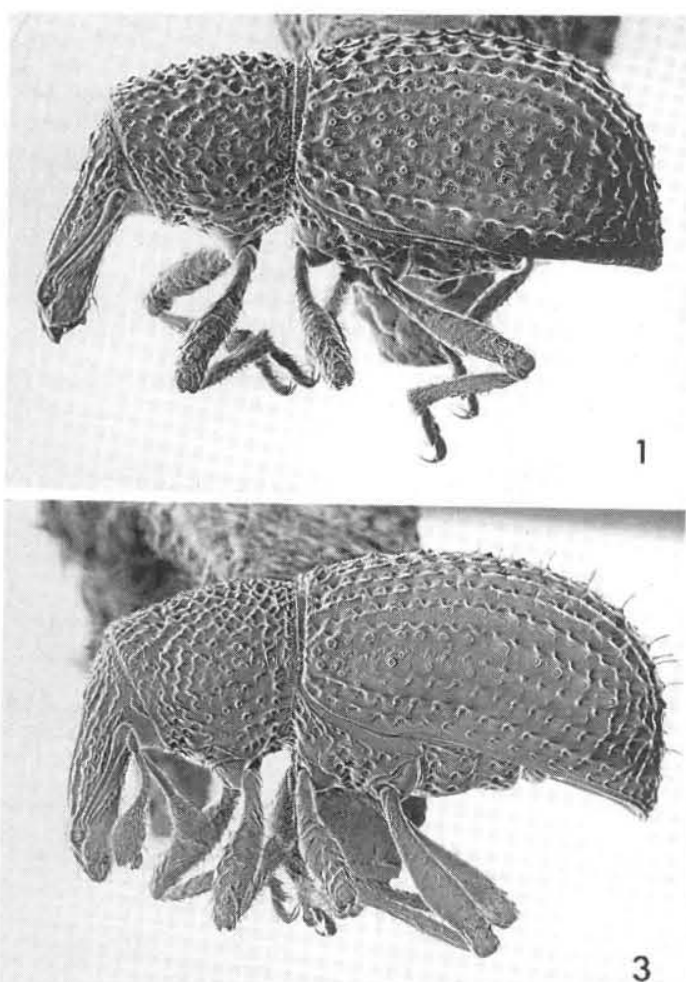

3

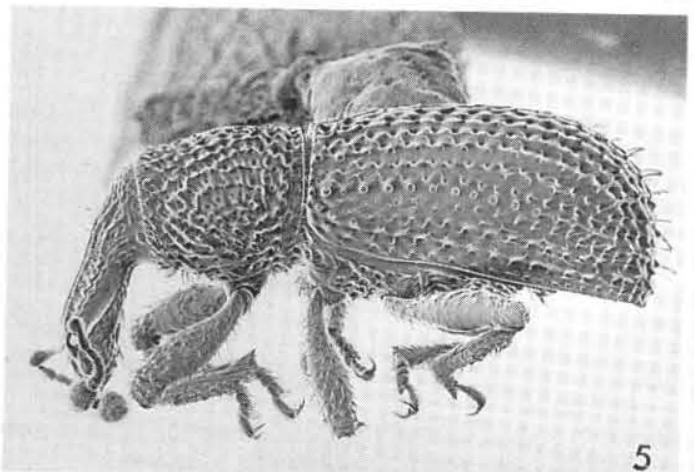

5

Figs 1-6. Dorsal and lateral habitus of Andesianellus spp.: (1, 2) A minutus; $(3,4)$ A planirostris; $(5,6)$ A tricar inatus.
Etymology. - The name of the genus refers to the occurrence of its species throughout the Andes Mts of northern South America. Gender masculine.

Diagnosis. - Species of this genus are easily recognized by their very small size (less than $3.5 \mathrm{~mm}$ in length), reduced eyes composed of 8 or fewer facets, dorsally tricarinate rostrum, and raised, subcarinate basal elytral margin.
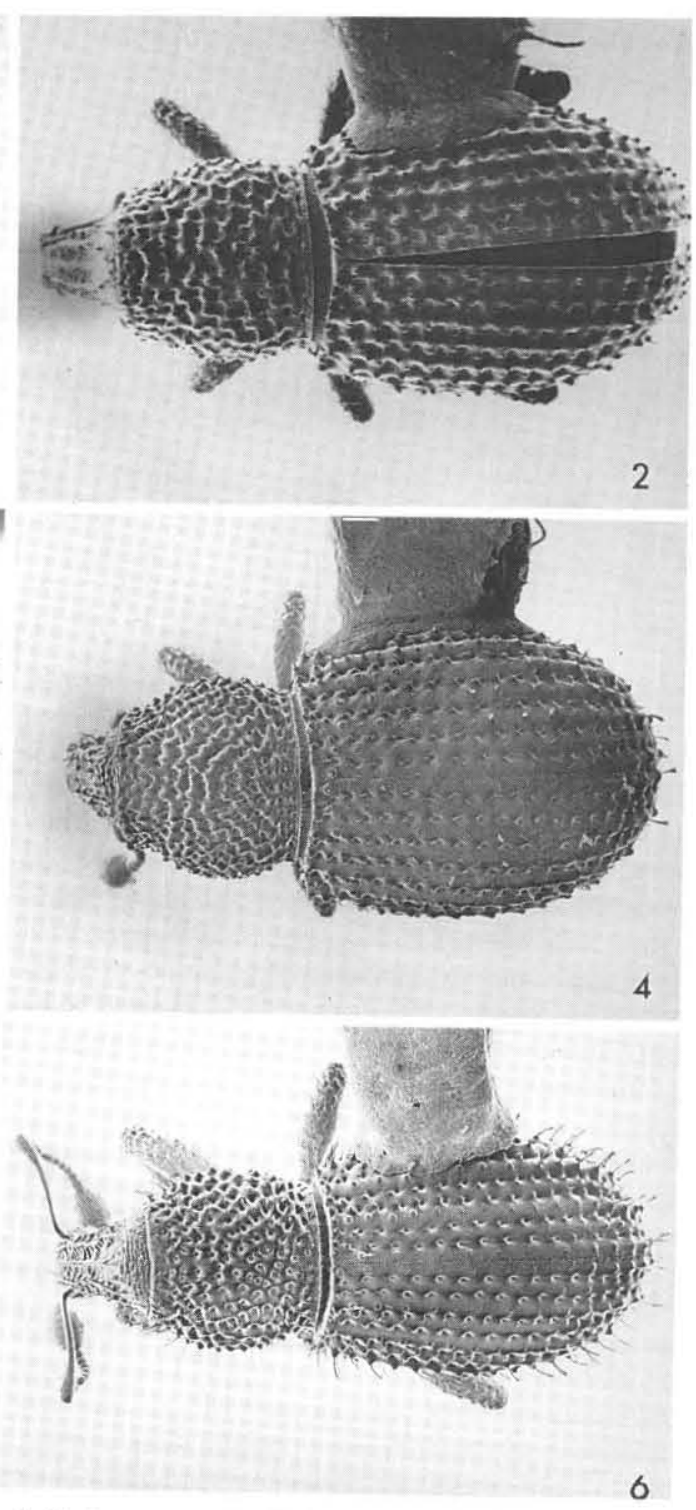
Description. - Very small weevils (Figs 1-18), : $\quad 1.9-3.3 \mathrm{~mm}$ in length. Colour dark red-brown, legs and antennae lighter orange-brown to yellowbrown. Vestiture of small, fine, recumbent to erect setae; some species with erect clavate setae on pronotum and elytra, some species with appressed setae of rostrum and anterior portion of pronotal disk singly or multiply cleft almost to base, appearing plumose. Eyes lateral, very small, composed of 8 or fewer facets. Rostrum elongate, slightly shorter than pronotum; straight to very slightly curved, distinctly tricarinate dorsally; point of antennal insertion subapical, not visible in dorsal view. Pterygia well developed. Scrobes lateral. Mouthparts (see Morrone et al. 1992 for descriptions of mouthparts of other Rhytirhinini) with mandible with 2 external setae, 2 apical teeth; maxillae with prominent palpifer, stipes with single seta, palpi with articles 1 and 2 wider than long, article 3 as long as wide; prementum subrectangular, lacking setae, sides slightly bowed, labial palpi with articles 1 and 2 wider than long, article 3 slightly longer than wide, setae 1-0-0. Antenna with scape clavate, reaching anterior margin of eye when resting in scrobe; article 1 longer than 2, 2 longer than 3, 3-7 moniliform; club inflated. Pronotum subcylindrical to transverse, coarsely punctured or sculptured, without postocular lobes. Hind wings absent. Scutellum visible. Metepisternal suture absent. Elytra oval to elongate-oval, with strial punctures large, deep, variously encroaching on interstriae; basal margin raised and subcarinate; stria 10 continuous to elytral apex or terminated opposite metacoxa; anteapical tubercles absent. Legs rather slender, tibiae with spurs minute, oriented parallel to longitudinal axis of tibia in some species, or, small, oriented obliquely to longitudinal axis of tibia in remaining species; tarsal article 3 bilobed, with long ventral pubescence; tarsal claws relatively large. Abdomen with ventrite I similar in males and females, not markedly sexually dimorphic; ventrites III and IV combined subequal to $\mathrm{V}$ in length. Genitalia. Male (Figs 19-30). Aedeagus
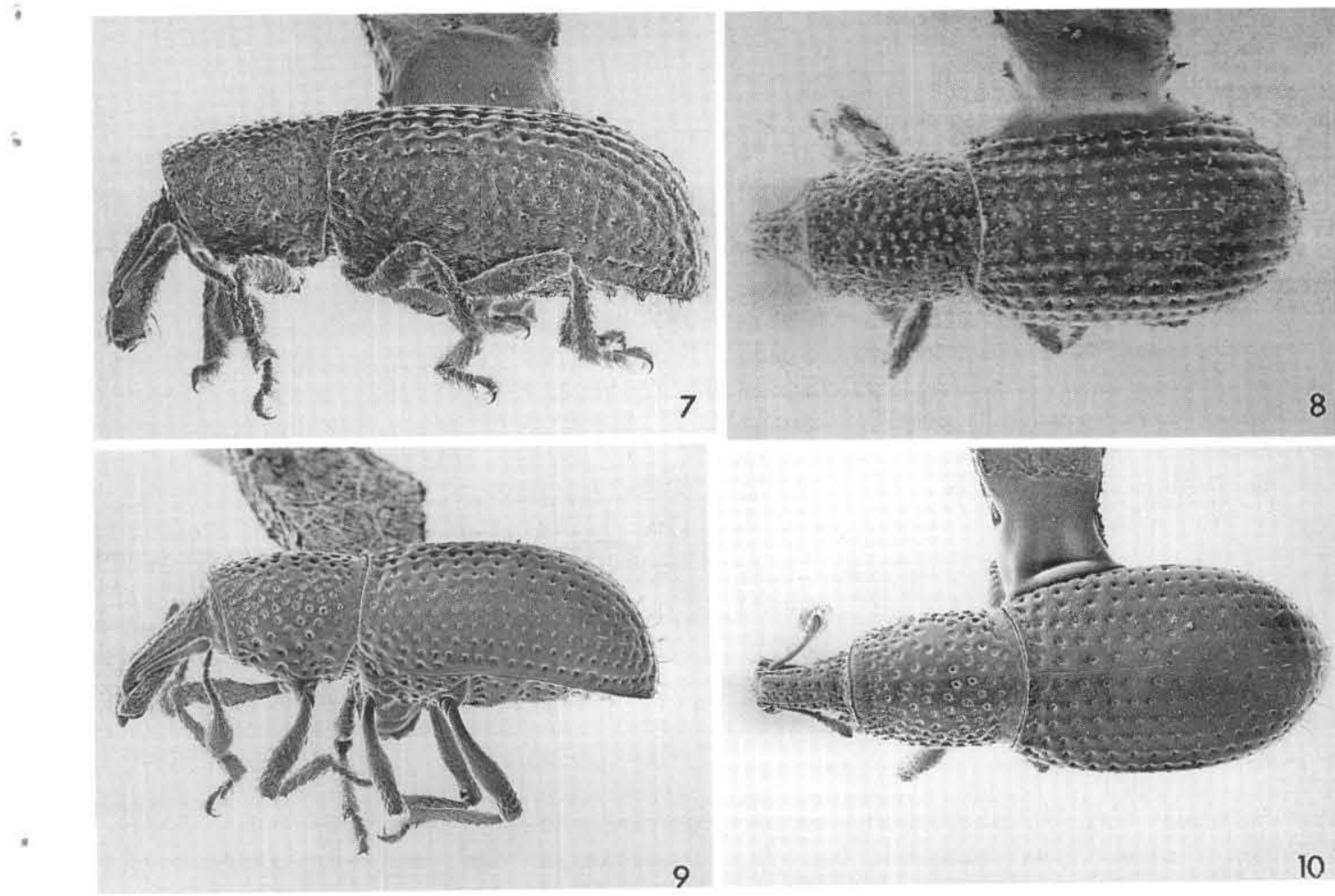

Figs 7-10. Dorsal and lateral habitus of Andesianellus spp.: (7, 8) A. microphthalmicus; $(9,10)$ A. fulgidus. 

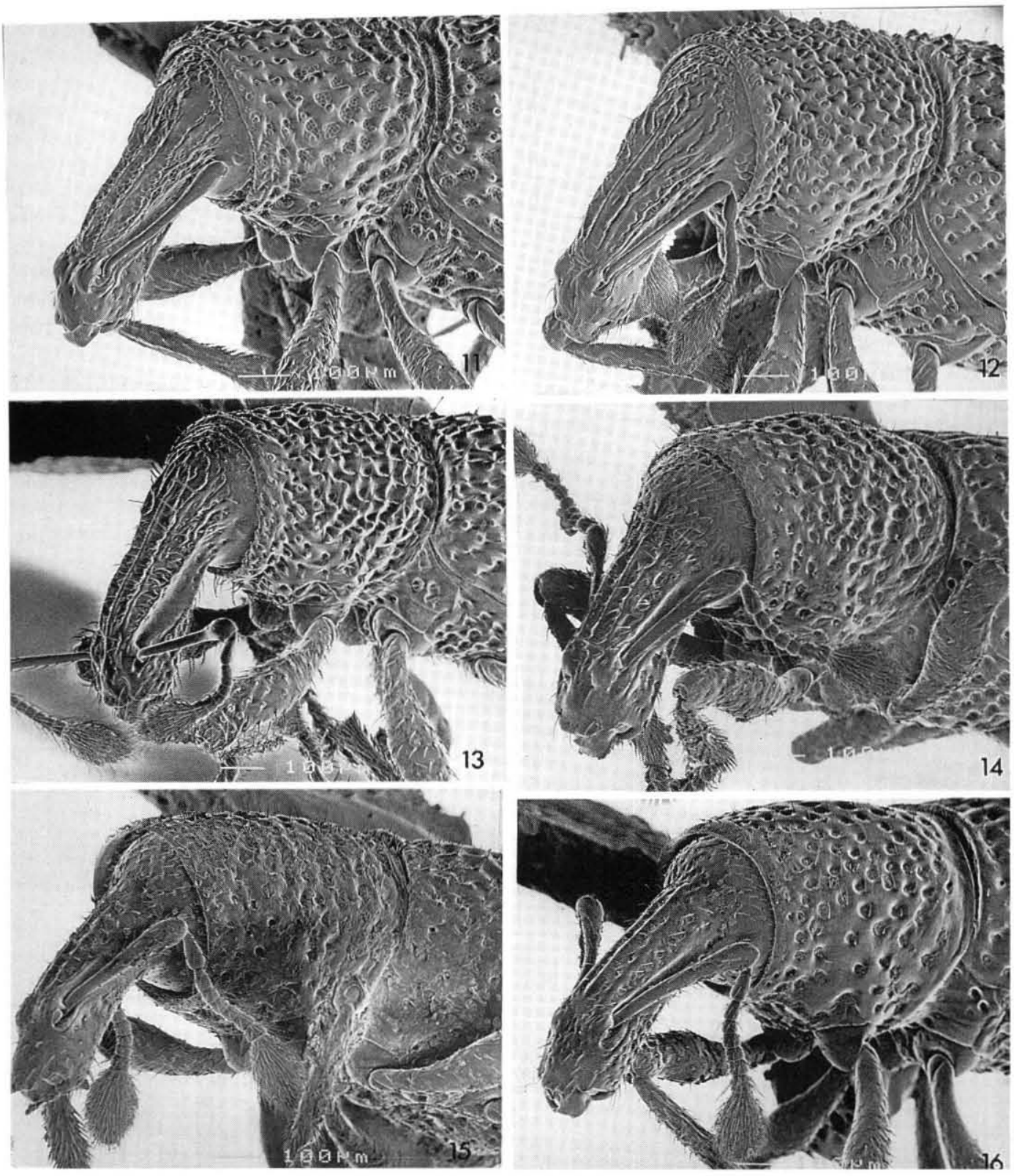

Figs 11-16. Head in left anterolateral view of Andesianellus spp.: (11) A. minutus; (12) A. planirostris; (13) A. tricarinatus; (14) A. masneri; (15) A. microphthalmicus; (16) A. fulgidus.

short, apodemes long; lightly or heavily sclerotized; apex produced or not; internal sac long (extended almost to apex apodemes), lacking extensive internal sclerotization. Female (Figs 31-54).
Sternum VIII with arms short, slightly arcuate, apical margin with long setae; apodeme very long, narrow. Hemisternite with stylus long, stylus with 2-4 long setae at apex; basally with elon- 
gate, curved, more heavily sclerotized projection

b ('baculus' of Morrone 1994c). Spermatheca with ramus short or elongate, nodulus flat or swollen, slightly to markedly subapical.

Included species. - Nine species of which seven can be placed in two rather distinct groups (Figs $56,57)$. One group comprised of four species $(A$. carltoni, A. cotopaxi, A. fulgidus, and A. microphthalmicus) is characterized by rostrum-frons juncture variously concave; dorsal margin of the antennal scrobe subcarinate in the basal half (not so near the eye where the rostrum is slightly dorsolaterally constricted and therefore not merged evenly with the head); appressed setae of rostrum and anterior portion of pronotal disk singly or multiply cleft almost to base, appearing plumose; stria 10 terminated opposite the metacoxa; setae of pronotum and/or elytra set flush with integument, not on tubercles; female genitalia with spermatheca with ramus (area of attachment of spermathecal gland) elongate, nodulus (area of attachment of spermathecal duct) markedly subapical (female not known for A. cotopaxi); and male genitalia with aedeagus lightly sclerotized, apex very slightly if at all produced (male not known for $A$. fulgidus). This contrasts with the second group (A. minutus, A. planirostris and A. tricarinatus) characterized by rostrum-frons juncture flat; dorsal margin of the antennal scrobe subcarinate throughout; rostrum not dorsolaterally constricted and therefore merged evenly with the head; appressed setae of rostrum and anterior portion of pronotal disk simple, not plumose; stria ten continued to elytral apex; at least some setae of pronotum and/or elytra (especially laterally near humeri) set on variously developed, small tubercles; female genitalia with spermatheca with ramus (area of attachment of spermathecal gland) not elongate, nodulus (area of attachment of spermathecal duct) very slightly subapical; and male genitalia with aedeagus heavily sclerotized, apex markedly produced (male not known for $A$. minutus).

Both A. hermani (male not known) and A. masneri possesses some character states of the former group (rostrum-frons juncture concave; appressed setae of rostrum and anterior portion of pronotal disk cleft, appearing plumose; spermatheca with ramus elongate, nodulus markedly subapical; and male genitalia with aedeagus lightly sclerotized, apex very slightly if at all produced [A. masneri only]) and some character states of the latter group (stria 10 continued to elytral apex; and at least some setae of pronotum andor elytra set on small tubercles). Cladistic analysis shows both $A$. masneri and $A$. hermani belong to the first group with A. carltoni, A. cotopaxi, A. fulgidus, and A. microphthalmicus.

Biology. - Most specimens of this genus have been collected in berlese samples of various kinds of forest litter and some in pan traps set on the ground substrate. Specimens have been collected at $2500-4000 \mathrm{~m}$ in Ecuador, $2000 \mathrm{~m}$ in Colombia, and $1000 \mathrm{~m}$ and $2450-2880 \mathrm{~m}$ in Peru.

Distribution. - Species in this genus are found in the Andean highlands of Colombia, Ecuador, and Peru (Fig. 55).

Phylogenetic relationships. - The closest relatives of Andesianellus appear to be the Andean genera Adioristidius Voss and Macrostyphlus Kirsch.

\section{Key to species of Andesianellus}

1. Stria 10 continuous to elytral apex (although shallowly impressed beyond metacoxa in some specimens) (Figs 1, 3, 5); at least some setae on pronotum and/or elytra (especially laterally near humeri) set on variously developed, small tubercles (Figs 1-6). Colombia, Ecuador, and Peru ........................................... 9); setae of pronotum and/or elytra set flush with integument, not set on tubercles (Figs 710). Ecuador...

2. Setae of rostrum and pronotum simple (Figs 11-13); base of rostrum and frons merged evenly, rostral-frons juncture flat (Figs 11-13); pronotum transverse. Peru .................................... 3

- Many setae of rostrum and pronotum singly or multiply cleft almost to base, appearing plumose (Fig. 14); base of rostrum and frons not merged evenly, rostral-frons juncture concave (Fig. 14); pronotum subcylindrical. Ecuador and Colombia ......................................................... 5

3. Some long erect setae of dorsum distinctly clavate (Figs 4, 6); body length greater than $1.75 \mathrm{~mm}$ (of most specimens greater than 2.10 $\mathrm{mm}$ )

All erect setae of dorsum simple, not clavate (Fig. 2); body length less than $2.00 \mathrm{~mm}$............. A. minutus sp. $\mathrm{n}$

4. Body form more oval, l:w of elytra 1.18-1.35 (Fig. 4); eye composed of about 7 facets (Fig. 12) ............................................... planirostris sp. n.

- Body form more elongate-oval, l:w of elytra 1.42-1.53 (Fig. 6); eye composed of single facet (Fig. 13) ............................... A. tricarinatus sp.n.

5. Rostral-frons juncture very slightly concave; 
cleft setae of rostrum and pronotum appressed, short. Ecuador …....................... A. masneri sp. n.

- Rostral-frons juncture moderately concave; cleft setae of rostrum and pronotum suberect to erect (especially on rostrum), longer, wispy. Colombia ………...................... A. hermani sp. n

6. Body size small $(2.3-2.6 \mathrm{~mm})$.. A. hermani sp. n.

- Body size larger (3.0-3.3 mm)

7. Dorsal erect setae of pronotum and elytra uniformly short, about as long as diameter of a puncture; punctures at dorsal base of rostrum small, shallow, not contiguous, rostrum-frons juncture not subrugose; punctures of ventrite II moderately dense, scattered

A. microphthalmicus sp. $\mathrm{n}$

- Dorsal erect setae of pronotum and base of elytra short, slightly longer than diameter of a puncture, setae at and beyond apical declivity longer, about 3 times diameter of a puncture; punctures at dorsal base of rostrum moderately large, deep, contiguous, rostrum-frons juncture subrugose; punctures of ventrite II sparse and few, arranged in more or less transverse row ........................................... A. carltoni sp. n.

8. Some elytral setae beyond apical declivity twice length of setae on disk; eve composed of single facet; ventrites I and II with scattered, moderately large punctures ........... A. fulgidus sp. n.

- Some elytral setae beyond apical declivity at most only slightly longer than length of setae on disk; eye composed of 7-8 facets; ventrites I and II with very few, small punctures A. cotopaxi sp. n.

\section{Andesianellus minutus sp. $\mathbf{n}$.}

(Figs 1, 2, 11, 31-33, 55)

Etymology. - This species is named 'minutus' because it is the smallest species in the genus.
Diagnosis. - This species is recognized by the small body size, oval body form, and erect vestiture of dorsal surface simple and set on tubercles.

Description. - Holotype female. Length $2.00 \mathrm{~mm}$; width $0.98 \mathrm{~mm}$. Colour yellow-brown, legs and antennae lighter yellow-brown. Head with vertex and frons dull, appearing impunctate; with very small, fine recumbent setae intermixed with fine erect setae on frons. Frons with deep irregular rugae at juncture with base of rostrum. Dorsal margin of scrobe subcarinate and 'shelf-like' almost to eye; rostrum not dorsolaterally constricted at base, merged evenly with head. Base of rostrum and frons continuous, rostrum-frons juncture flat. Eye lateral, very small, composed of 2 or 3 dorsoventrally, linearly arranged facets; narrowly covered by anterolateral margin of pronotum. Rostrum straight, impunctate laterally and between carinae; in dorsal view narrowest at about midlength, wider apically at point of antennal insertion and basally; apical one-third shiny, not distinctly punctate, slightly swollen dorsally at point of antennal insertion. Pronotum transverse, slightly wider than long $(\mathrm{l}: \mathrm{w}=0.89)$; surface of disk dull, coarsely sculptured, individual punctures indistinct; raised areas with small, acute tubercles, each bearing single erect short seta. Elytra ovate $(\mathrm{l}: \mathrm{w}=1.36)$; punctures of striae very large and deep, markedly encroaching on interstriae. Interstriae dull, very narrow, with scattered small acute tubercles each bearing single erect short seta; stria 10 continuous but narrow beyond metacoxa to

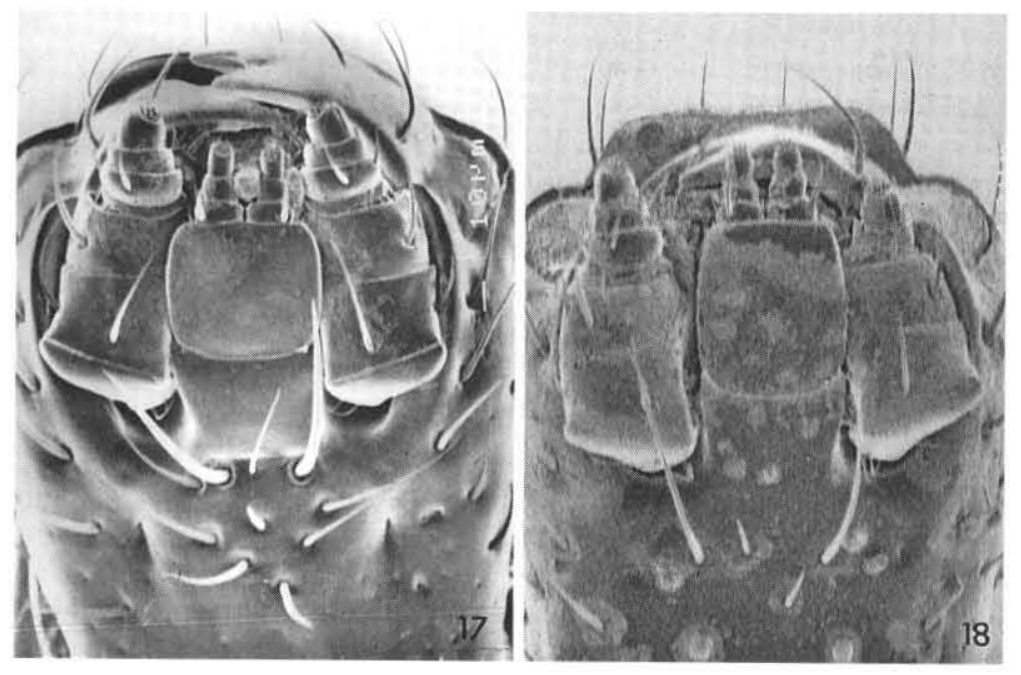

Figs 17, 18. Mouthparts in ventral view of Andesianellus spp.: (17) A. planirostris; (18) A. microphthalmicus.
$=$ 
elytral apex. Abdomen with ventrites I and II shiny, with scattered large, shallow punctures; punctures large, deep along anterior margin ventrite I. Ventrites III-V shiny, impunctate. Ventrites $\mathrm{I}-\mathrm{V}$ with short, fine, erect setae; ventrite $\mathrm{V}$ with setae longer, especially along apical margin. Ventrites III and IV together slightly longer than V. Legs slender with scattered fine erect setae throughout; femora slightly clavate; tibiae with inner margin straight, apical spurs of hind and middle tibiae minute, oriented parallel to longitudinal axis of tibia. Genitalia. Spermatheca (Fig. 32) with ramus not elongate, nodulus slightly swollen, very slightly subapical. Sternum VIII (Fig. 31). Hemisternite (Fig. 33).

Male. Unknown.

Variation. Female $(n=3)$. Length 1.90-2.00 mm. Width 0.95-0.98 mm. Pronotum l:w 0.891.00. Elytra l:w 1.30-1.36.

Type material. - Holotype, female, PERU: Cuzco Dept., Pillahuata, Manu rd. km. 128, 16.ix.1982, ex litter under ferns, Watrous \& Mazurek (FMNH). Paratypes, PERU: 2 females, Cuzco Dept., Pillahuata, Manu rd. $\mathrm{km}$. 128, 18.ix.1982, litter in dry streambed, Watrous \& Mazurek (CMNC, FMNH).

Notes. - Andesianellus minutus has been collected sympatrically and synchronically with $A$. planirostris. Whereas $A$. planirostris appears to be very common in the samples examined by us, $A$. minutus is contrastingly rare. There are no elevations given on the labels for the collection locality of this species; Stephens \& Traylor (1983) give the elevation of 'Pillahuata' as $2450-2880 \mathrm{~m}$ and note the surrounding habitat as open bushy slopes and elfin cloud forest.

\section{Andesianellus planirostris sp. $\mathbf{n}$.}

(Figs 3, 4, 12, 17, 19, 20, 34-36, 55)

Etymology: - This species is named 'planirostris' because of the evenly merged rostrum and frons, the juncture between the two areas being flat.

Diagnosis. - This species is recognized by oval body form, erect setae of dorsal surface clavate and set on tubercles, and eyes with from five to seven facets.

Description. - Holotype male. Length $2.18 \mathrm{~mm}$; width $1.19 \mathrm{~mm}$. Colour dark red-brown, legs and antennae orange-brown. Head with vertex and frons shiny, vertex subtuberculate, individual punctures indistinct; vertex with very small, fine recumbent setae; frons slightly bulbous medially, impunctate but with five or six low irregular rugae. Dorsal margin of scrobe subcarinate and 'shelf-like' almost to eye; rostrum not dorsolaterally constricted at base, merged evenly with head. Base of rostrum and frons continuous, rostrumfrons juncture flat. Eye lateral, small, composed of seven dorsoventrally linearly oriented facets. Rostrum very slightly curved, sulci impunctate; with scattered sparse fine erect setae; in dorsal view narrowest immediately before point of antennal insertion, wider apically at point of antennal insertion and gradually basally; apical onethird shiny, impunctate, slightly swollen dorsally at point of antennal insertion. Pronotum transverse, slightly wider than long $(\mathrm{l}: \mathrm{w}=0.87)$; disk somewhat shiny, coarsely sculptured, individual punctures indistinct; unimpressed areas with low, rounded tubercles, each bearing single fine short erect seta. Elytra oval $(1: \mathrm{w}=1.18)$; punctures of elytral striae large and deep; punctures encroaching on interstriae. Interstriae shiny, narrow (third and fifth interstriae slightly wider), with moderately dense short recumbent setae and sparse, longer erect clavate setae, the latter about 2-3 times diameter of puncture in length and set on variously developed tubercles; stria 10 continuous to elytral apex Abdomen with ventrites I and II shiny, with moderately dense, large shallow punctures; punctures large, deep along anterior margin ventrite I. Ventrites III-V shiny, impunctate. Ventrites I-V with short, fine, erect setae; ventrite V in apical one-half with setae very long, about as long as ventrite IV at middle. Ventrites III and IV together very slightly longer than V. Legs slender, with scattered fine erect setae throughout; femora slightly clavate; tibiae with inner margin straight, apical spurs of all tibiae small, but well developed, oriented obliquely to longitudinal axis of tibia. Genitalia. Aedeagus (Figs 19-20) with body moderate, apodemes moderate (as long as length body of aedeagus); heavily sclerotized; lateral margins convergent, apex gradually produced and markedly acuminate; internal sac long, extended to apex of apodemes, with small scattered spicules in apical one-third.

Allotype female. Length $2.35 \mathrm{~mm}$. Width 1.26 mm. Pronotum $(\mathrm{l}: \mathrm{w}=0.84)$. Elytra $(\mathrm{l}: \mathrm{w}=1.25)$. Genitalia. Spermatheca (Fig. 35) with ramus not elongate, nodulus swollen, very slightly subapical. Sternum VIII (Fig. 34). Hemisternite (Fig. 36). 
Variation. Male $(\mathrm{n}=5)$. Length 1.76-2.53 mm. Width 0.95-1.26 mm. Pronotum l:w 0.79-0.87. Elytra l:w 1.18-1.35. Female $(n=5)$. Length 1.93$2.39 \mathrm{~mm}$. Width 1.02-1.26 mm. Pronotum l:w 0.75-0.85. Elytra l:w 1.25-1.28. Number of eye facets varies from five to seven.

Type material. - Holotype, male, PERU: Cuzco Dept., Pillahuata, Manu rd. km. 128, 16.IX.1982, ex litter under ferns, Watrous \& Mazurek (FMNH). Allotype, female, PERU: Cuzco Dept., Pillahuata, Manu rd. 128 $\mathrm{km}, 26 . \mathrm{IX} .1982$, ex leaf litter, Watrous \& Mazurek (FMNH). Paratypes, PERU: 9 females, Cuzco Dept., Pillahuata, Manu Rd. 128 km, 26.IX.1982, ex leaf litter, Watrous \& Mazurek; 11 females, Cuzco Dept., Pillahuata, Manu rd. $128 \mathrm{~km}, 25 . I X .1982$, ex vine litter, Watrous \& Mazurek; 15 females, 1 male, Cuzco Dept., Pillahuata, Manu Rd. 165 km, 27.IX.1982, ex vine litter, Watrous \& Mazurek; 1 female, Cuzco Dept., Pillahuata, Manu Rd. 128 km, 21.IX.1982, ex litt. mossy for. slope, Watrous \& Mazurek; 11 females, Cuzco Dept., Pillahuata, Manu rd. km. 128, 26.IX.1982, litter along stream, Watrous \& Mazurek; 1 female, Cuzco Dept., Pillahuata, Manu rd. km. 128, 26.IX.1982, ex litter along streambed, Watrous \& Mazurek; 13 females, 6 males, Cuzco Dept., Pillahuata, Manu rd. km. 128, 16.IX.1982, ex litter under ferns, Watrous \& Mazurek; 10 females, 1 male, Cuzco Dept., Pillahuata, Manu rd. km. 128, 26.IX.1982, ex vine litter, Watrous \& Mazurek; 3 females, Cuzco Dept., Pillahuata, Manu rd. km. 128, 18.IX.1982, ex litter in dry streambed, Watrous \& Mazurek; 3 females, Cuzco Dept., Pillahuata, Manu rd. km. 128, 20.IX.1982, ex litter under ferns, Watrous \& Mazurek; 10 females, Cuzco Dept., Pillahuata, Manu rd. km. 128, 20.IX.1982, litter in mossy for., Watrous \& Mazurek; 6 females, 1 male, Cuzco Dept., Pillahuata, Manu rd. km. 128, 27.IX.1982, litter in runoff in mossy forest, Watrous \& Mazurek; 6 females, 1 male, Cuzco Dept., Pillahuata, Manu rd. km. 128, 26.IX.1982, moss \& litter-xeric slope, Watrous \& Mazurek; 9 females, Cuzco Dept., Pillahuata, Manu rd. km. 128, 19.IX.1982, ex litter after rain, Watrous \& Mazurek; 1 female, Cuzco Dept., Pillahuata, Manu rd. km. 128, 21.IX.1982, leaf litter after rain. Watrous \& Mazurek: 3 females, 2 males, Cuzco Dept., Pillahuata, Manu rd. km. 128. 26.IX.1982, damp If.litt., Watrous \& Mazurek; 27 females, 2 males, Cuzco Dept., Pillahuata, Manu rd. km. 128, 24.IX.1982, ex vine litter, Watrous \& Mazurek; 11 females, Cuzco Dept., Pillahuata, Manu rd. km. 128, 20.IX.1982, ex litter in mossy forest, Watrous \& Mazurek; 3 females, Cuzco Dept., Pillahuata, Manu rd. km. 128, 19.IX.1982, ex leaf litter, Watrous \& Mazurek; 5 females, 1 male, Cuzco Dept., Pillahuata, Manu rd. km. 128, 17.IX.1982, ex leaf litter. Watrous \& Mazurek; 6 females, 1 male, Cuzco Dept., Pillahuata, Manu rd. km. 128, 24.IX.1982, ex leaf litter, Watrous \& Mazurek; 6 females, Cuzco Dept., Pillahuata, Manu rd. km. 128, 26.IX.1982, ex rotten logs, Watrous \& Mazurek; 9 females, 2 males, Cuzco Dept. Consuelo, Manu Rd. 165 km. 4.X.1982, ex leaf litter, Watrous \& Mazurek. Paratypes in AMNH, BMNH, CMNC, CWOB, FMNH, HAHC, MLP and USNM.

Notes. - Andesianellus planirostris has been col- lected sympatrically and synchronically with $A$. minutus and sympatrically with A. tricarinatus. There are no elevations given on the labels for the collection localities of this species; Stephens \& Traylor (1983) give the elevation of 'Pillahuata' as $2450-2880 \mathrm{~m}$ and note the surrounding habitat as open bushy slopes and elfin cloud forest and give the elevation of 'Consuelo' as $1000 \mathrm{~m}$ and note the habitat as upper tropical forest.

\section{Andesianellus tricarinatus sp. $\mathbf{n}$.}

(Figs 5, 6, 13, 21, 22, 37-39, 55)

Etymology. - This species is named 'tricarinatus' because of the markedly tricarinate rostrum.

Diagnosis. - This species is recognized by elongate-oval body form, erect setae of dorsal surface clavate and set on tubercles, and eyes with a single facet.

Description. - Holotype male. Length $2.11 \mathrm{~mm}$; width $0.95 \mathrm{~mm}$. Colour dark red-brown, legs and antennae yellow-brown. Head with vertex and frons dull, appearing impunctate but markedly rugose; vertex with very small, fine recumbent setae; frons above eye with 1 or 2 long erect clavate setae and slightly shorter fine erect setae. Scrobe deep, dorsal margin subcarinate and 'shelf-like' almost to eye; rostrum not dorsolaterally constricted at base, merged evenly with head. Base of rostrum and frons continuous, rostrum-frons juncture flat. Eye lateral, very small, composed of single facet. Rostrum very slightly curved, carinae extended as rugae onto frons; sulci between carinae deep, pitted but individual punctures indistinct; in dorsal view narrowest at about midlength, very slightly wider apically at point of antennal insertion and basally; apical one-quarter shiny, irregularly sparsely punctate, slightly swollen dorsally at point of antennal insertion. Pronotum transverse, slightly wider than long $(\mathrm{l}: \mathrm{w}=0.88)$; disk with deep dense irregular punctures; raised areas between punctures somewhat shiny; punctures individually distinct, laterally areas between punctures with small, acute tubercles; margins of punctures with moderately dense erect clavate setae, about 1.5-2 times diameter of a puncture in length. Elytra elongate-oval $(\mathrm{l}: \mathrm{w}=1.42)$; punctures of elytral striae moderately large and deep; punctures slightly encroaching on interstriae. Interstriae shiny, moderate in width (third and
* 
ENT. SCAND. VOL. 27:3 (1996)

New genus of microphthalmic weevils 267
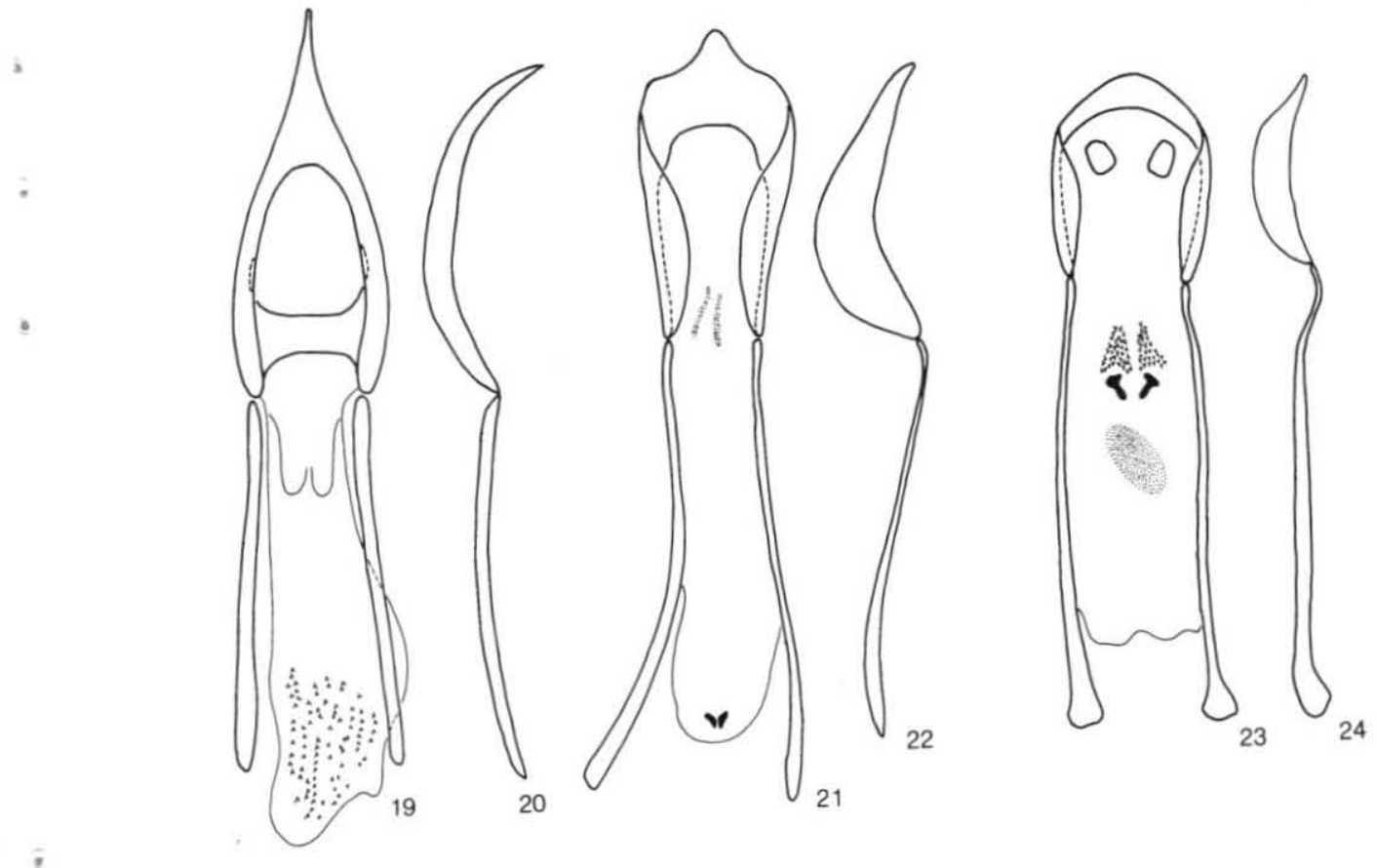

$\bullet$
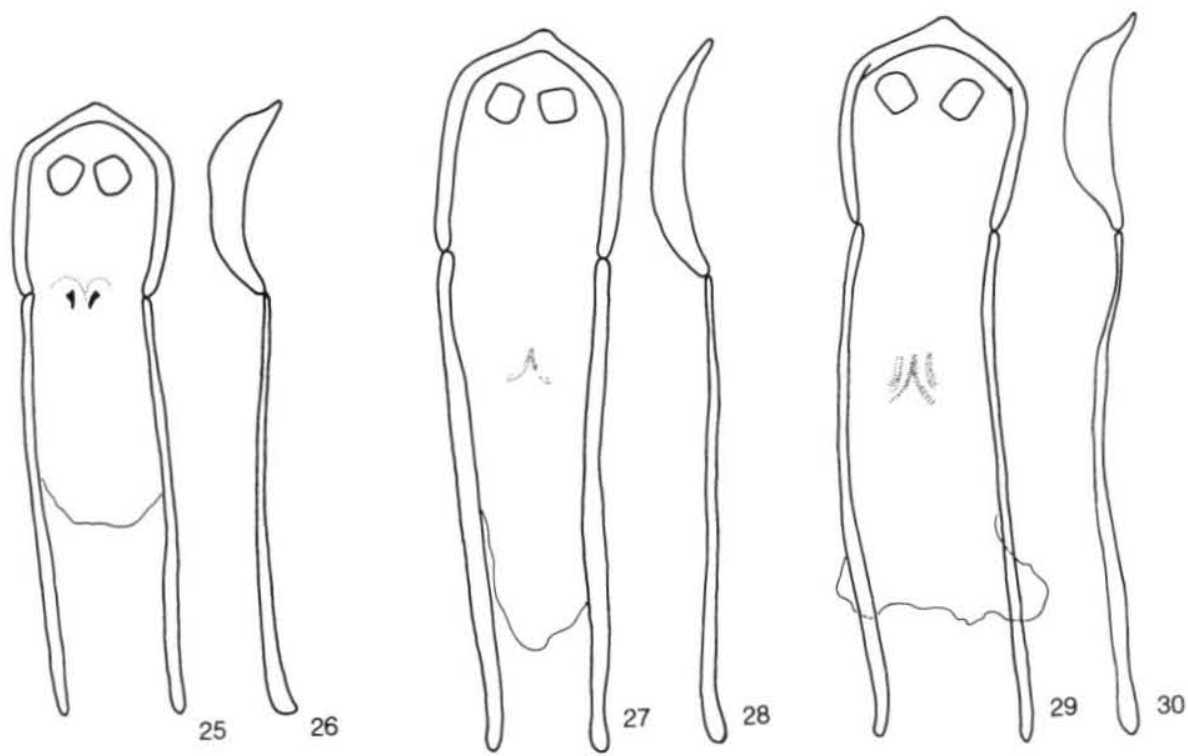

Figs 19-30. Male genitalia of Andesianellus spp: $(19,20)$ A. planirostris; $(21,22)$ A. tricarinatus; $(23,24)$ A. masneri; $(25,26)$ A. microphthalmicus; $(27,28)$ A. carltoni; $(29,30)$ A. cotopaxi. 
fifth interstriae slightly wider), with linearly arranged dense erect clavate setae about 1.5 times as long as diameter of puncture; laterally and apically with setae set on small acute tubercles; stria 10 continuous to elytral apex Abdomen with ventrites I and II shiny, with moderately dense, irregular, moderately large punctures; punctures large, deep along anterior margin ventrite I. Ventrites III-V shiny, impunctate. Ventrites I-V with short, fine, erect setae; ventrite $\mathrm{V}$ with setae slightly longer along apical margin. Ventrites III and IV together about as long as V. Legs somewhat robust, with scattered fine erect setae throughout; femora slightly clavate; tibiae with inner margin straight, apical spurs of all tibiae small, but well developed, oriented obliquely to longitudinal axis of tibia. Genitalia. Aedeagus (Figs 21-22) with body moderate, apodemes long (1.5 times length body of aedeagus); heavily sclerotized; lateral margins subparallel to near apex, then convergent to apex, apex markedly abruptly produced and broadly acuminate; internal sac long, extended to apex of apodemes, with pair of small spicules near apex

Allotype female. Length $2.39 \mathrm{~mm}$. Width 1.05 $m m$. Pronotum $(\mathrm{l}: \mathrm{w}=0.91)$. Elytra $(\mathrm{l}: \mathrm{w}=1.53)$. Genitalia. Spermatheca (Fig. 38) with ramus not elongate, nodulus swollen, very slightly subapical. Sternum VIII (Fig. 37). Hemisternite (Fig. 39).

Variation. Female $(\mathrm{n}=3)$. Length 2.18-2.46 mm. Width 0.98-1.09 mm. Pronotum l:w 0.901.00. Elytra 1:w 1.46-1.53. Male $(n=2)$. Length 2.11-2.49 mm. Width 0.95-1.16 mm. Pronotum l:w 0.88-0.95. Elytra l:w 1.42-1.48.

Type material. - Holotype, male, PERU: Cuzco Dept., Consuelo, Manu Rd. 165 km, 12.X.1982, ex leaf litter, Watrous \& Mazurek (FMNH). Allotype, female, PERU: Cuzco Dept., Consuelo, Manu Rd. 165 km, 12.X.1982, ex leaf litter, Watrous \& Mazurek (FMNH). Paratypes, PERU: 1 female, same data as holotype; 1 female, same data as holotype except 'ex rotten palm'; 1 male, same data as holotype except '2.X.1982', 'ex litter under tree'. Paratypes in CMNC and FMNH.

Notes. - Andesianellus tricarinatus has been collected sympatrically with A. planirostris. There are no elevations given on the labels for the collection locality of this species; Stephens \& Traylor (1983) give the elevation of 'Consuelo' as $1000 \mathrm{~m}$ and note the surrounding habitat as upper tropical forest.

\section{Andesianellus masneri sp. $\mathbf{n}$.}

(Figs 14, 23, 24, 40-42, 55)

Etymology. - This species is named 'masneri' after our colleague Lubomir Masner who collected the two known specimens.

Diagnosis. - This species is recognized by the cleft, appressed, plumose scales of the dorsum of the rostrum and the pronotum, rostral-frons juncture very slightly concave, and elytral stria 10 continuous to the elytal apex

Description. - Holotype male. Length 2.95 mm; width $1.40 \mathrm{~mm}$. Colour dark red-brown, tarsi and antennae yellow-brown. Head with vertex and frons shiny, with small scattered punctures and very small, fine recumbent, simple or cleft setae. Dorsal margin of scrobe subcarinate throughout apical one-half, not so basally near eye. Base of rostrum and frons continuous, rostrum-frons juncture very slightly concave. Eye lateral, small, composed of 6 facets. Rostrum slightly curved, deeply punctate laterally and between carinae, some punctures with setae singly or multiply cleft almost to base, appearing plumose; punctures sparse, separate at base of rostrum; in dorsal view narrowest at midlength, very slightly wider apically at point of antennal insertion and basally; apical one-third shiny, finely punctate, slightly swollen dorsally at point of antennal insertion. Pronotum subcylindrical, slightly longer than wide $(1: \mathrm{w}=1.08)$; disk shiny, with coarse deep punctures; individual punctures distinct, moderately large and uniformly dense; margins of punctures with fine, erect setae about as long as diameter of puncture; some punctures with appressed setae, multiply cleft almost to base, appearing plumose. Elytra elongate-oval $(1: w=1.38)$; punctures of elytral striae moderately large and deep basally, shallow and small towards and at apical declivity; punctures slightly encroaching on interstriae. Interstriae shiny, narrow, with scattered elongate fine erect setae; basally, setae short, about as long as diameter of puncture; apically, setae slightly longer than at base, length 2-3 times diameter of puncture; laterally near humeri with setae set on small rounded tubercles; stria 10 continuous to elytral apex but shallowly, indistinctly impressed beyond metacoxa. Abdomen with ventrites I and II shiny, with moderately dense shallow punctures; punctures large, deep along anterior margin ventrite I. Ventrites III-V shiny, with shallow scattered punctures. Ventrites I and II vir- 
tually glabrous, with only isolated, fine short setae; ventrites III-V with setae denser, longer, erect. Ventrites III and IV together longer than V. Legs slender with scattered fine erect setae throughout; femora slightly clavate; tibiae with inner margin straight, apical spurs of hind and middle tibiae minute, oriented parallel to longitudinal axis of tibia. Genitalia. Aedeagus (Figs 23$24)$ with body short, apodemes long ( 2.5 times length body of aedeagus); lightly sclerotized; lateral margins subparallel to near apex, then convergent to apex, apex very slightly produced; internal sac long, extended to near apex of apodemes, with minute denticles and pair of small sclerites at midlength, and oval sclerotized patch at about apical one-third.

Allotype female. Length $2.74 \mathrm{~mm}$. Width 1.30 mm. Pronotum $(\mathrm{l}: \mathrm{w}=1.17)$. Elytra $(\mathrm{l}: \mathrm{w}=1.30)$. Genitalia. Spermatheca (Fig. 41) with ramus elongate, nodulus swollen, markedly subapical. Sternum VIII (Fig. 40). Hemisternite (Fig. 42).

Type material. - Holotype, male, ECUADOR: Pich., Quito-Baeza road, $4000 \mathrm{~m}$, Paramo, summer 1983, pan trap, Masner (CMNC). Allotype, female, ECUADOR:

7 Napo, Quito- Baeza road, 4000 m, 24.II.1983, Masner (CMNC).

\section{- Andesianellus hermani sp. n.}

(Figs 43-45, 55)

Etymology. - This species is named 'hermani' after our colleague Lee Herman who collected the holotype.

Diagnosis. - This species is recognized by the deeply cleft, suberect to erect, plumose scales of the dorsum of the rostrum and the pronotum, rostral-frons juncture moderately concave, and elytral stria 10 continuous to the elytal apex It is the only species of Andesianellus known from Colombia.

Description. - Holotype female. Length $2.60 \mathrm{~mm}$; width $1.26 \mathrm{~mm}$. Colour dark red-brown, legs and antennae red-brown. Head with vertex and frons moderately shiny, finely and shallowly punctate; vertex with small, fine recumbent setae; frons with setae slightly longer, more dense, some singly cleft almost to base. Dorsal margin of scrobe throughout apical one-half, not so basally near eye. Base of rostrum and frons merged at angle, rostrum-frons juncture concave. Eye lateral, small, composed of 5 facets. Rostrum slightly curved; with few large irregular punctures lateral- ly and between carinae; setae moderately dense, erect, many singly or multiply cleft almost to base, appearing plumose; in dorsal view narrowest at about midlength, very slightly wider apically at point of antennal insertion and basally; apical one-quarter shiny, irregularly sparsely punctate, slightly swollen dorsally at point of antennal insertion. Pronotum subcylindrical, slightly longer than wide $(\mathrm{l}: \mathrm{w}=1.09)$; disk with deep dense punctures; areas between punctures somewhat shiny; punctures individually distinct; margins of punctures with moderately dense erect simple setae, about 1.5-2 times diameter of a puncture in length; some punctures with appressed to suberect setae, multiply cleft almost to base, appearing plumose. Elytra oval $(\mathrm{l}: \mathrm{w}=1.28)$; punctures of elytral striae moderately large and deep; punctures slightly encroaching on interstriae. Interstriae shiny, moderate in width, with linearly arranged erect fine simple setae about 1.5 times as long as diameter of puncture at base, slightly longer at and beyond apical declivity; laterally near humeri with setae set on small rounded tubercles; stria 10 continuous to elytral apex Abdomen with ventrites I and II shiny, with moderately dense, irregular, moderately large punctures; punctures deep along anterior margin ventrite I. Ventrites III-V shiny, impunctate. Ventrites I-V with short, fine, erect setae; ventrite V with setae slightly longer along apical margin. Ventrites III and IV together slightly longer than V. Legs slender, with scattered fine erect setae throughout; femora slightly clavate; tibiae with inner margin straight, apical spurs of hind and middle tibiae minute, oriented parallel to longitudinal axis of tibia. Genitalia. Spermatheca (Fig. 44) with ramus elongate, nodulus flat, markedly subapical. Sternum VIII (Fig. 43). Hemisternite (Fig. 45).

Male. Unknown.

Type material. - Holotype, female, COLOMBIA: Cundinamarca, Aguadita, III-10-1974, leaf litter, Herman (AMNH).

Notes. - There is no elevation indicated on the label attached to the specimen; Paynter \& Traylor (1981) give the elevation of 'La Aguadita' as ca. $2000 \mathrm{~m}$.

\section{Andesianellus microphthalmicus sp. $\mathbf{n}$.}

(Figs 7, 8, 15, 18, 25, 26, 46-48, 55)

Etymology. - This species is named 'microphthalmicus' 

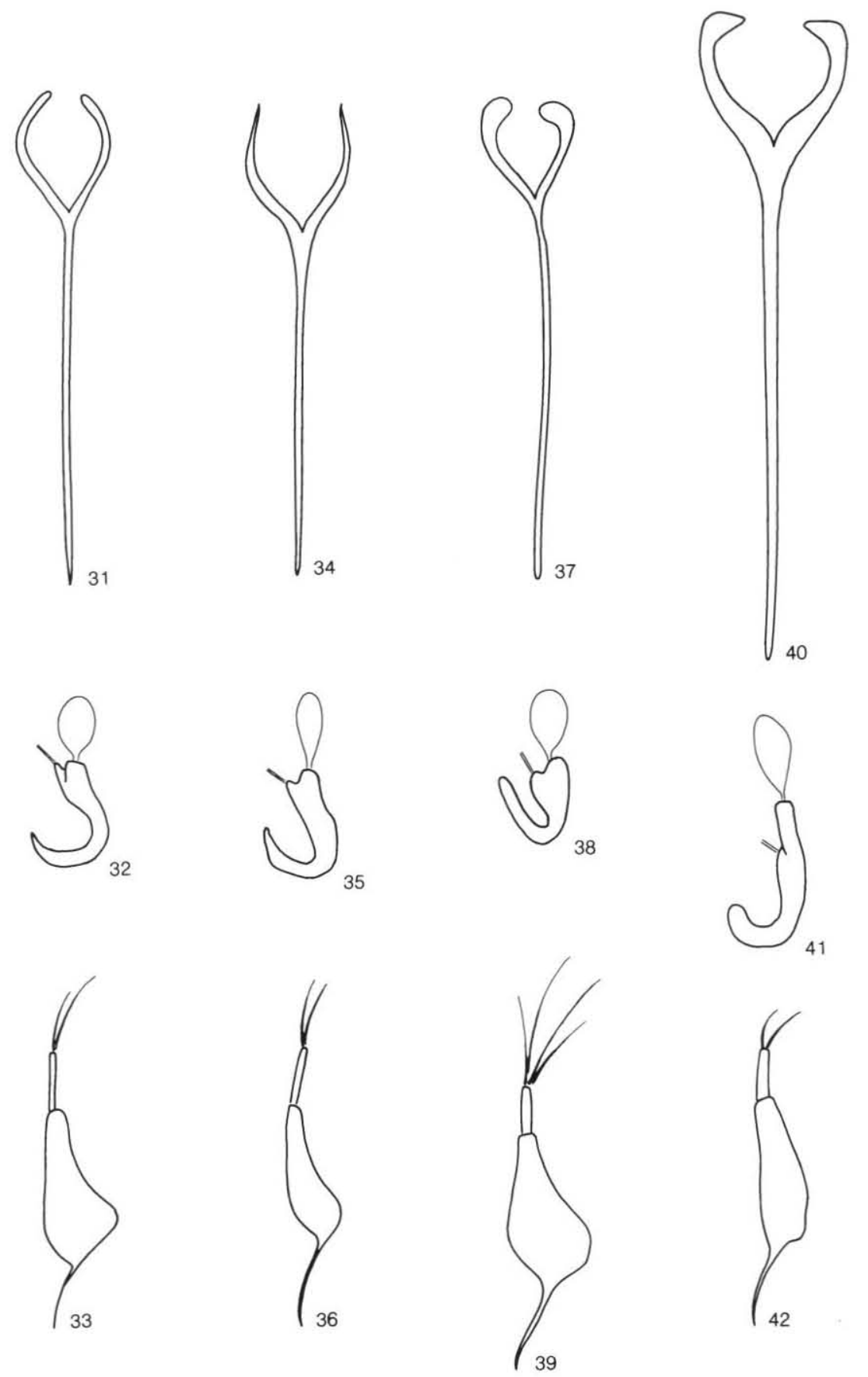

Figs 31-42. Female genitalia of Andesianellus spp.: (31-33) A. minutus; (34-36) A. planirostris; (37-39) A. tricarinatus; (40-42) A. masneri. 
ENT. SCAND. VOL. 27:3 (1996)
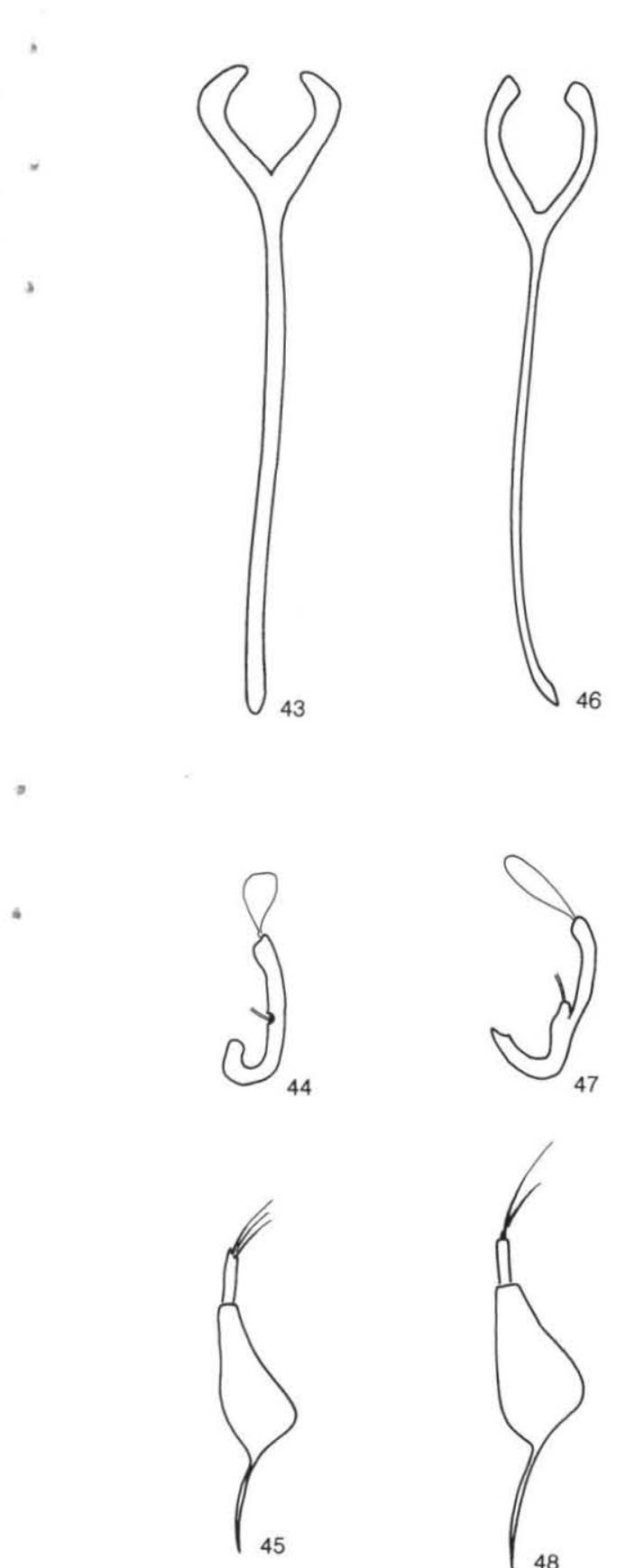

New genus of microphthalmic weevils 271
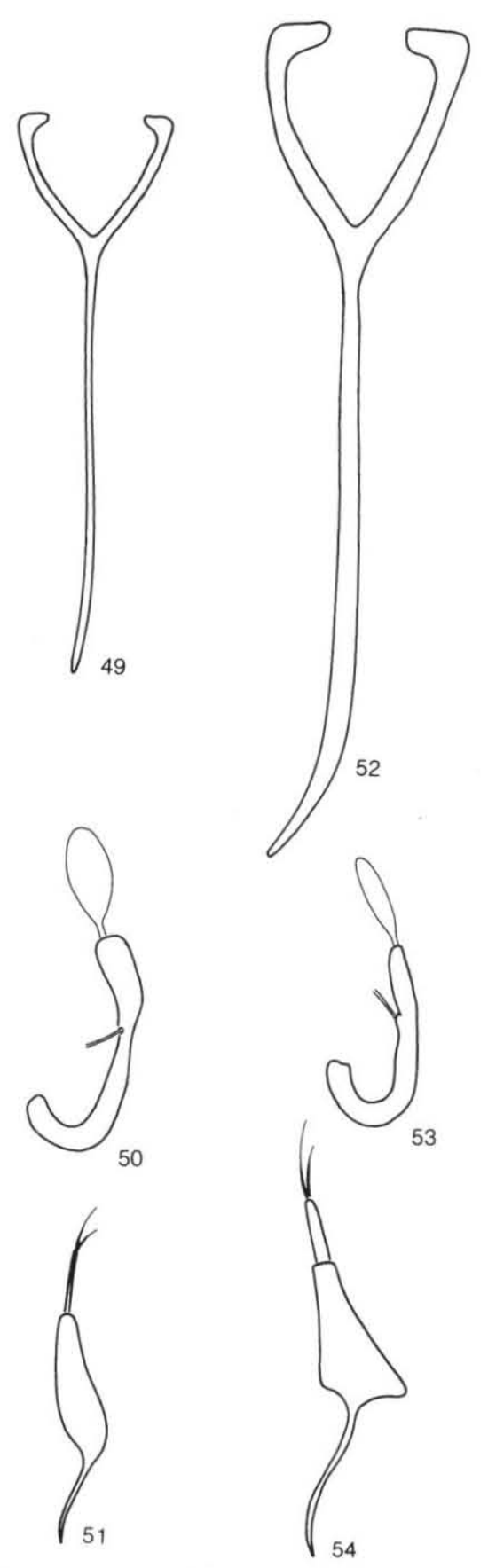
Figs 43-54. Female genitalia of Andesianellus spp.: (43-45) A. hermani; (46-48) A. microphthalmicus; (49-51) A.
carltoni; (52-54) A. fulgidus. 
because of the very small eyes composed of only a single facet.

Diagnosis. - This species is recognized by elytral stria 10 terminated opposite metacoxa, erect setae of pronotum andor elytra uniform in length, set flush with integument, not set on tubercles, and body size small.

Description. - Holotype male. Length $2.32 \mathrm{~mm}$; width $1.12 \mathrm{~mm}$. Colour dark red-brown, legs and antennae yellow-brown. Head with vertex and frons shiny, with small scattered punctures and very small, fine recumbent setae, some cleft, appearing plumose. Dorsal margin of scrobe subcarinate throughout most of length, not so basally near eye where rostrum dorsolaterally constricted, not merged evenly with head. Base of rostrum and frons merged at angle, rostrum-frons juncture concave. Eye lateral, very small, composed of single facet. Rostrum very slightly curved, distinctly punctate laterally and between carinae, some punctures with setae singly or multiply cleft almost to base, appearing plumose; punctures at base of rostrum small, shallow, separate, not subrugose in appearance; in dorsal view narrowest from basal one-quarter to apical one-third, wider apically at point of antennal insertion, only slightly wider basally; apical one-third shiny, not distinctly punctate, slightly swollen dorsally at point of antennal insertion. Pronotum subcylindrical, longer than wide $(\mathrm{l}: \mathrm{w}=1.10)$; disk shiny, with large deep dense punctures; individual punctures distinct, slightly smaller and some confluent anteriorly; margins of punctures with fine, erect setae slightly longer than diameter of puncture; some punctures with appressed setae, multiply cleft almost to base, appearing plumose. Elytra elongateoval $(\mathrm{l}: \mathrm{w}=1.41)$; punctures of elytral striae large and deep basally, slightly smaller at apical declivity; punctures encroaching on interstriae. Interstriae shiny, narrow, with elongate fine erect setae; setae short, about as long as diameter of puncture throughout; stria 10terminated opposite metacoxa. Abdomen with ventrites I and II shiny, with moderately dense and moderately deep punctures; punctures large, deep along anterior margin ventrite I. Ventrites III-V shiny, impunctate. Ventrites I-IV with very short, sparse, fine, suberect to erect setae; ventrite $\mathrm{V}$ with setae longer, especially along apical margin. Ventrites III and IV together slightly longer than V. Legs robust with scattered fine erect setae throughout; femora moderately clavate; tibiae with inner margin straight, apical spurs of hind and middle tibiae minute, oriented parallel to longitudinal axis of tibia. Genitalia. Aedeagus (Figs 25-26) with body short, apodemes long (2.5 times length body of aedeagus); lightly sclerotized; lateral margins subparallel to near apex, then convergent to apex, apex very slightly produced; internal sac long, extended to midlength of apodemes, with pair of small basal sclerites.

Allotype female. Length $2.49 \mathrm{~mm}$. Width 1.09 mm. Pronotum $(\mathrm{l}: \mathrm{w}=1.20)$. Elytra $(\mathrm{l}: \mathrm{w}=1.32)$. Genitalia. Spermatheca (Fig. 47) with ramus elongate, nodulus swollen, markedly subapical. Sternum VIII (Fig. 46). Hemisternite (Fig. 48).

Variation. Female $(n=4)$. Length 2.28-2.32 mm. Width $1.12 \mathrm{~mm}$. Pronotum l:w 1.15-1.20. Elytra l:w 1.31-1.34. Male $(n=6)$. Length 2.32 mm. Width 1.02-1.12 mm. Pronotum l:w 1.111.15. Elytra l:w 1.34-1.55.

Type material. - Holotype, male, ECUADOR: Azuay Prov., Cajas, 25 km. NW. Cuenca, 3700 m, 7 Jan. 1992. \#106 ex: berlese, Carlton \& Leschen (CMNC). Allotype, female, ECUADOR: Azuay Prov. Rio Mazan Reserve, $10 \mathrm{~km}$. NW. Cuenca, $3150 \mathrm{~m}$, 2.i.1992, berlese Podocarpus forest, Carlton \& Leschen (CMNC). Paratypes, ECUADOR: 3 females, 4 males as allotype; 1 male, Azuay Prov., $15 \mathrm{~km}$. NNW Cuenca, Mazan Forest, 3200 m, 16 Apr. 1990, Podocarpus litter berleseate, Carlton \& Adarve. Paratypes in CMNC and MLP.

\section{Andesianellus carltoni $\mathbf{s p} . \mathbf{n}$.}

(Figs 27, 28, 49-51, 55)

Etymology: - This species is named 'carltoni' after our colleague Chris Carlton who collected the type series of this species as well as specimens of other species of $A n$ desianellus.

Diagnosis. - This species is recognized by elytral stria 10 terminated opposite metacoxa, erect setae of pronotum andor elytra not uniform in length (those at and beyond elytral declivity longer), set flush with integument, not set on tubercles, and body size small.

Description. - Holotype male. Length $2.32 \mathrm{~mm}$; width $1.05 \mathrm{~mm}$. Colour dark red-brown, legs and antennae yellow-brown. Head with vertex and frons shiny, with small scattered punctures and very small, fine recumbent, simple or cleft setae. Dorsal margin of scrobe subcarinate throughout most of length, not so basally near eye where rostrum dorsolaterally constricted, not merged even- 


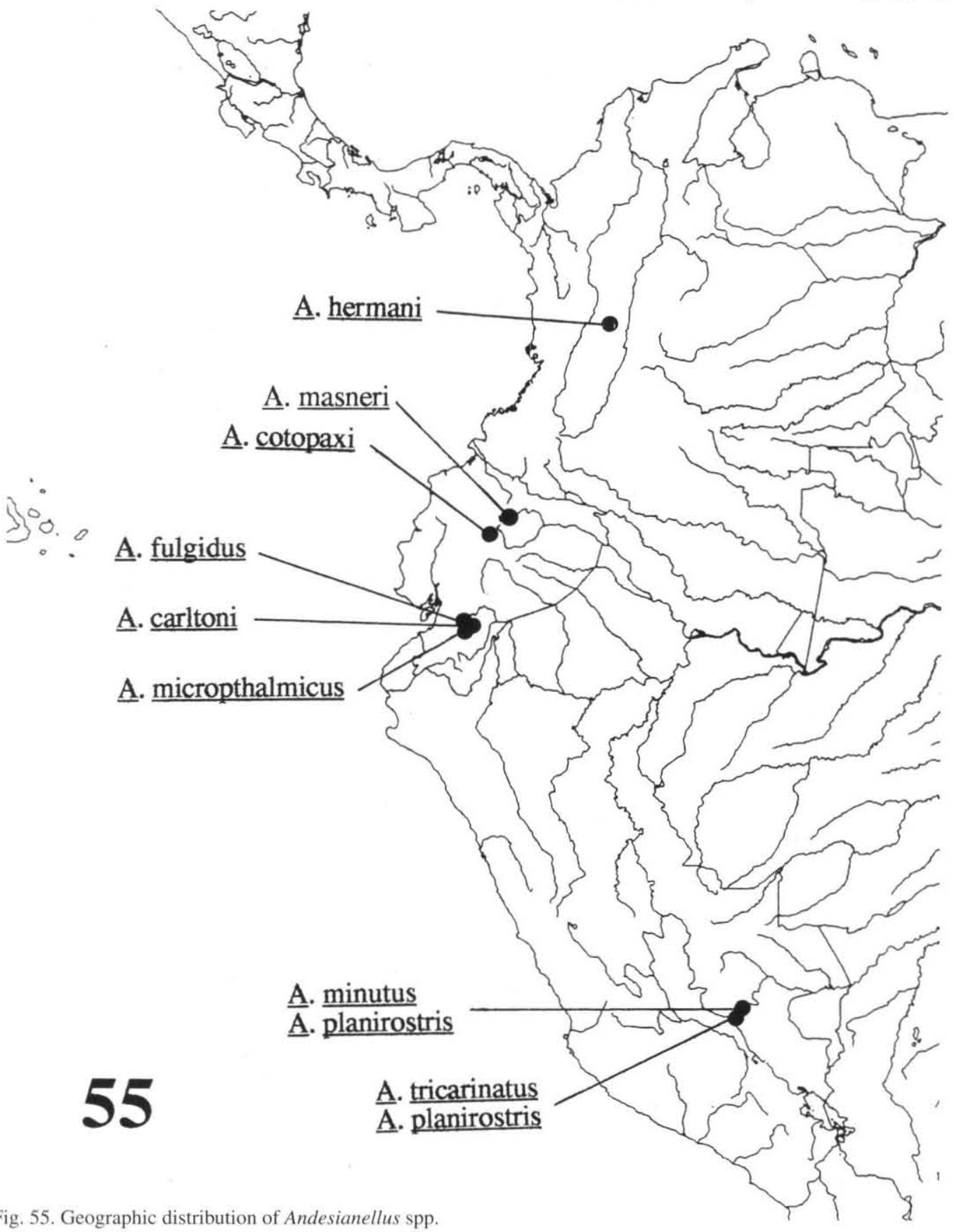

Fig. 55. Geographic distribution of Andesianellus spp.

very slightly curved, distinctly punctate laterally and between carinae; punctures contiguous at base of rostrum, subrugose in appearance, many ly with head. Base of rostrum and frons merged at angle, rostrum-frons juncture concave. Eye lateral, very small, composed of single facet. Rostrum 
punctures with setae singly or multiply cleft almost to base, appearing plumose; in dorsal view narrowest from basal one-quarter to apical onethird, wider apically at point of antennal insertion. only slightly wider basally; apical one-third shiny, not distinctly punctate, slightly swollen dorsally at point of antennal insertion. Pronotum subcylindrical, longer than wide $(l: w=1.09)$; disk shiny, with large deep dense punctures; individual punctures distinct, slightly smaller and some confluent anteriorly; margins of punctures with fine, erect setae slightly longer than diameter of puncture; some punctures with appressed setae, multiply cleft almost to base, appearing plumose. Elytra elongate-oval $(\mathrm{l}: \mathrm{w}=1.47)$; punctures of elytral striae large and deep basally, slightly smaller at apical declivity; punctures encroaching on interstriae. Interstriae shiny, narrow, with elongate fine erect setae; basally, setae short, slightly longer than diameter of puncture; apically, setae about twice as long as at base, length about 3 times diameter of puncture; stria 10 terminated opposite metacoxa. Abdomen with ventrites I and II shiny, with irregular scattered shallow punctures; punctures large, deep along anterior margin ventrite I; punctures of ventrite II sparse, arranged in transverse row. Ventrites III-V shiny, impunctate. Ventrites I-IV with very short, sparse, fine, suberect to erect setae; ventrite V with setae longer, especially along apical margin. Ventrites III and IV together slightly longer than V. Legs robust with scattered fine erect setae throughout; femora moderately clavate; tibiae with inner margin straight, apical spurs of hind and middle tibiae minute, oriented parallel to longitudinal axis of tibia. Genitalia. Aedeagus (Figs 27-28) with body short, apodemes long ( 2.5 times length body of aedeagus); lightly sclerotized; lateral margins subparallel to near apex, then convergent to apex, apex very slightly produced; internal sac long, extended to apical two-thirds of apodemes, with indistinct patch of minute denticles near midlength.

Allotype female. Length $2.60 \mathrm{~mm}$. Width 1.19 mm. Pronotum $(1: \mathrm{w}=1.09)$. Elytra $(\mathrm{l}: \mathrm{w}=1.41)$. Genitalia. Spermatheca (Fig. 50) with ramus elongate, nodulus flat, markedly subapical. Sternum VIII (Fig. 49). Hemisternite (Fig. 51).

Variation. Female $(n=2)$. Length 2.53-2.60 mm. Width $1.19 \mathrm{~mm}$. Pronotum l:w 1.04-1.09. Elytra 1:w 1.38-1.41.

Type material. - Holotype, male, ECUADOR: Azuay Prov, $30 \mathrm{~km}$. NE Paute at Paute Hydrological Com- pound, $2500 \mathrm{~m}, 19 \mathrm{Apr} .1990$, for. remnant $\log$ and tree base berleseate, Carlton \& Adarve (CMNC). Allotype, female, labelled as holotype (CMNC). Paratype female, labelled as holotype (CMNC).

\section{Andesianellus fulgidus sp. $\mathrm{n}$.}

(Figs 9, 10, 16, 52-55)

Etymology. - This species is named 'fulgidus' because of the shining appearance.

Diagnosis. - This species is recognized by elytral stria 10 terminated opposite metacoxa, erect setae of pronotum andor elytra not uniform in length (those at and beyond elytral declivity twice length of setae on elytral disk), set flush with integument, not set on tubercles, eye composed of single facet, and body size large for genus.

Description. - Holotype female. Length $3.30 \mathrm{~mm}$; width $1.37 \mathrm{~mm}$. Colour dark red-brown, tarsi and antennae yellow-brown. Head with vertex and frons shiny, with small scattered punctures and very small, fine recumbent, simple or cleft setae. Dorsal margin of scrobe subcarinate throughout apical one-half, not so basally near eye where rostrum dorsolaterally constricted, not merged evenly with head. Base of rostrum and frons merged at angle, rostrum-frons juncture concave. Eye lateral, very small, composed of single facet. Rostrum slightly curved, distinctly punctate laterally and between carinae; punctures contiguous laterally at base of rostrum, subrugose in appearance, many punctures with setae singly or multiply cleft almost to base, appearing plumose; in dorsal view narrowest at midlength, wider apically at point of antennal insertion, only slightly wider basally; apical one-third shiny, finely punctate, slightly swollen dorsally at point of antennal insertion. Pronotum subcylindrical, much longer than wide $(\mathrm{l}: \mathrm{w}=$ $1.32)$; disk shiny, with coarse deep punctures; individual punctures distinct, large and well-separated medially, smaller and denser anteriorly and laterally; margins of punctures with fine, erect setae about as long as diameter of puncture; some punctures with appressed setae, multiply cleft almost to base, appearing plumose. Elytra elongateoval $(\mathrm{l}: \mathrm{w}=1.56)$; punctures of elytral striae moderately large and deep basally, shallow and very small towards and at apical declivity; punctures not encroaching on interstriae. Interstriae shiny, broad, with scattered elongate fine erect setae; basally, setae short, about as long as diameter of 
TABLE 1: Character state matrix for species of Andesianellus.

\begin{tabular}{|c|c|c|c|c|}
\hline & $\begin{array}{l}00000 \\
12345\end{array}$ & $\begin{array}{l}00001 \\
67890\end{array}$ & $\begin{array}{l}11111 \\
12345\end{array}$ & $\begin{array}{l}11112 \\
67890\end{array}$ \\
\hline Adioristidius Voss & 00000 & 00000 & 00000 & 00000 \\
\hline Macrostyphlus Kirsch & 00000 & 01001 & 00000 & 00000 \\
\hline A. masneri & 10111 & 11111 & 00101 & 10101 \\
\hline A. hermani & 10111 & 11111 & 00101 & $1 ? ? 11$ \\
\hline A. minutus & 12120 & 11001 & 10101 & $1 ? ? 00$ \\
\hline A. planirostris & 12110 & 11001 & 11101 & 01000 \\
\hline A. tricarinatus & 12130 & 11001 & 11101 & 01000 \\
\hline A. microphthalmicus & 10131 & 11111 & 00021 & 10101 \\
\hline A. carltoni & 11131 & 11111 & 00021 & 10111 \\
\hline A. fulgidus & 11131 & 11111 & 00021 & $1 ? ? 11$ \\
\hline A. cotopaxi & 11111 & 11111 & 00011 & $101 ? ?$ \\
\hline
\end{tabular}

puncture; apically, setae about twice as long as at base, length 3-4 (or more) times diameter of puncture; stria 10 terminated opposite metacoxa. Abdomen with ventrites I and II shiny, with irreg- ular scattered shallow punctures; punctures large, deep along anterior margin ventrite I. Ventrites III-V shiny, impunctate. Ventrites I and II with very short, sparse, fine, recumbent setae; ventrites III-V with setae longer, erect. Ventrites III and IV together longer than V. Legs slender with scattered fine erect setae throughout; femora slightly clavate; tibiae with inner margin straight, apical spurs of hind and middle tibiae minute, oriented parallel to longitudinal axis of tibia. Genitalia. Spermatheca (Fig. 53) with ramus elongate, nodulus flat, markedly subapical. Sternum VIII (Fig. 52). Hemisternite (Fig. 54).

Male. Unknown.

Variation. Female $(n=2)$. Length 3.23-3.30 mm. Width 1.30-1.37 mm. Pronotum 1:w 1.241.32. Elytra l:w 1.56-1.59.

Type material. - Holotype, female, and paratype, $1 \mathrm{fe}-$ male, ECUADOR: Azuay Prov., 45 km. N.E. Cuenca

Table 2. Equally parsimonius primary cladograms for Adioristidius, Macrostyphlus and species of Andesianellus (in parenthetical form).

(Adioristidius, (Macrostyphlus, (((A. masneri, (A. microphthalmicus, ((A. carltoni, A. fulgidus), A. cotopaxi $))), A$. * hermani), (A. minutus, (A. planirostris, A. tricarinatus $))))$

(Adioristidius, (Macrostyphlus, (((A. masneri, (A. microphthalmicus, (A. carltoni, A. fulgidus, A. cotopaxi))), A. hermani), (A. minutus, (A. planirostris, A. tricarinatus)))))

- (Adioristidius, (Macrostyphlus, ((A. masneri, (A. hermani, (A. microphthalmicus, ((A. carltoni, A. fulgidus), A. cotopaxi)))), (A. minutus, (A. planirostris, A. tricarinatus)))))

(Adioristidius, (Macrostyphlus, ((A. masneri, (A. hermani, (A. microphthalmicus, (A. carltoni, A. fulgidus, A. cotopaxi)))), (A. minutus, (A. planirostris, A. tricarinatus $)))))$

(Adioristidius, (Macrostyphlus, (((A. masneri, A. hermani), (A. microphthalmicus, ((A. carltoni, A. fulgidus), A. cotopaxi))), (A. minutus, (A. planirostris, A. tricarinatus)))))

(Adioristidius, (Macrostyphlus, (((A. masneri, A. hermani), (A. microphthalmicus, (A. carltoni, A. fulgidus, A. cotopaxi))), (A. minutus, (A. planirostris, A. tricarinatus)))))

(Adioristidius, (Macrostyphlus, ((((A. masneri, A. hermani), (A. microphthalmicus, (A. carltoni, A. fulgidus))), A. cotopaxi), (A. minutus, (A. planirostris, A. tricarinatus)))))

(Adioristidius, (Macrostyphlus, (((A. masneri, ((A. microphthalmicus, (A. carltoni, A. fulgidus)), A. cotopaxi)), A. hermani), (A. minutus, (A. planirostris, A. tricarinatus)))))

(Adioristidius, (Macrostyphlus, ((A. masneri, (A. hermani, ((A. microphthalmicus, (A. carltoni, A. fulgidus)), A. cotopaxi))), (A. minutus, (A. planirostris, A. tricarinatus $)))))$

(Adioristidius, (Macrostyphlus, ((A. masneri, (A. hermani, ((A. microphthalmicus, A. carltoni, A. fulgidus), A. cotopaxi))), (A. minutus, (A. planirostris, A. tricarinatus)))))

(Adioristidius, (Macrostyphlus, (((A. masneri, A. hermani), ((A. microphthalmicus, (A. carltoni, A. fulgidus)), A. cotopaxi)), (A. minutus, (A. planirostris, A. tricarinatus $))))$ )

(Adioristidius, (Macrostyphlus, ((((A. masneri, A. hermani), A. cotopaxi), (A. microphthalmicus, (A. carltoni, A. fulgidus))), (A. minutus, (A. planirostris, A. tricarinatus $))))$ ) 


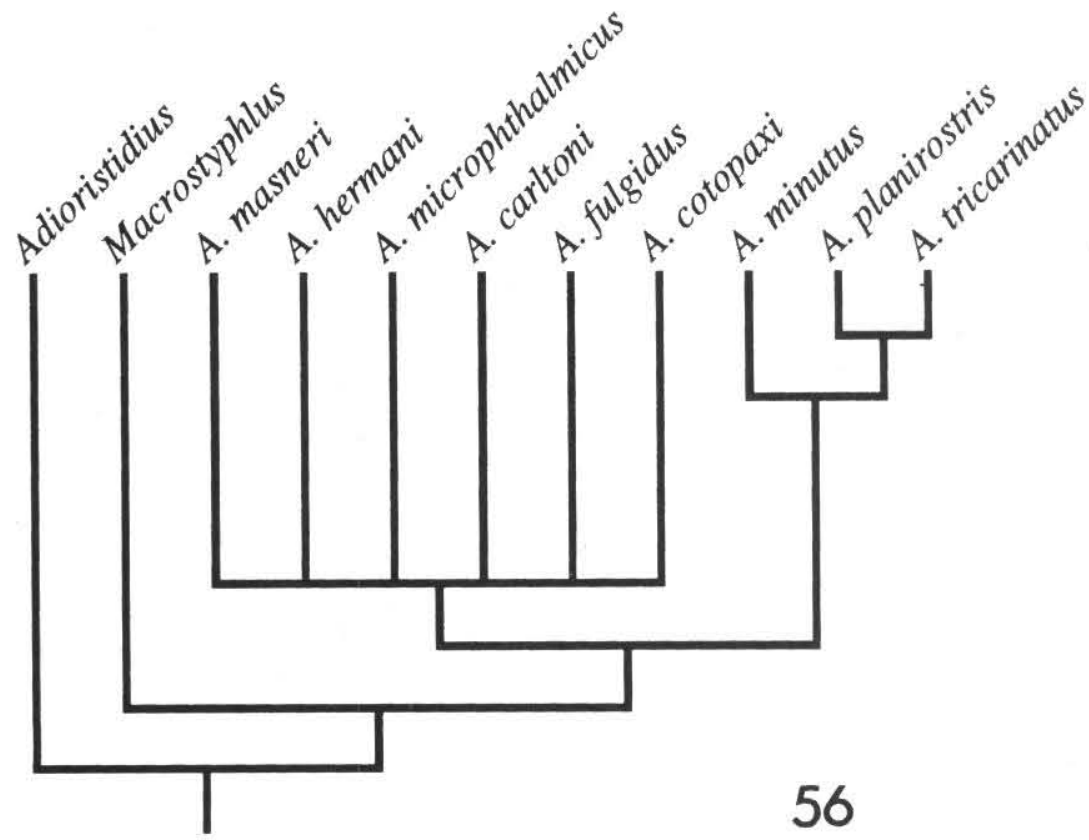

Figs 56. Consensus of 12 primary cladograms of Andesianellus spp. (see Table 2).

on Rd. to Sevilla de Oro, 2850 m. 3.i.1992, cloud forest berlese, Carlton \& Leschen (CMNC).

\section{Andesianellus cotopaxi sp. $\mathrm{n}$.}

(Figs 29, 30, 55)

Etymology. - This species is named 'cotopaxi' after the type locality in Cotopaxi National Park, Ecuador.

Diagnosis. - This species is recognized by elytral stria 10 interrupted opposite the metacoxa but continued opposite abdominal ventrite II, erect setae of pronotum andor elytra not uniform in length (those at and beyond elytral declivity only very slightly longer than setae on elytral disk), set flush with integument, not set on tubercles, eye composed of 7-8 facets, and body size large for genus.

Description. - Holotype male. Length $3.02 \mathrm{~mm}$; width $1.37 \mathrm{~mm}$. Colour dark red-brown, tarsi and antennae yellow-brown. Head with vertex and frons shiny, with small scattered punctures and very small, fine recumbent, simple or cleft setae. Dorsal margin of scrobe subcarinate throughout apical one-half, not so basally near eye. Base of rostrum and frons continuous, rostrum-frons juncture very slightly concave. Eye lateral, small, composed of 7-8 facets. Rostrum slightly curved, shallowly punctate laterally and between carinae, some punctures with setae singly or multiply cleft almost to base, appearing plumose; punctures sparse, separate at base of rostrum; in dorsal view narrowest at midlength, very slightly wider apically at point of antennal insertion and basally; apical one-third shiny, finely punctate, slightly swollen dorsally at point of antennal insertion. Pronotum subcylindrical, longer than wide $(\mathrm{l}: \mathrm{w}=$ 1.11); disk shiny, with coarse deep punctures; individual punctures distinct, large and well-separated medially, smaller and denser anteriorly and laterally; margins of punctures with fine, erect setae about as long as diameter of puncture; some punctures with appressed setae, multiply cleft almost to base, appearing plumose. Elytra elongateoval $(\mathrm{l}: \mathrm{W}=1.38)$; punctures of elytral striae moderately large and deep basally, shallow and small towards and at apical declivity; punctures not encroaching on interstriae. Interstriae shiny, broad, with scattered elongate fine erect setae; basally, setae short, about as long as diameter of puncture;
及 
apically, setae slightly longer than at base, length 2-3 times diameter of puncture; stria 10 terminated opposite metacoxa but very shallowly impressed again from opposite ventrite II to apex Abdomen with ventrites I and II shiny, with irreg-

- ular scattered shallow punctures; punctures large, deep along anterior margin ventrite I. Ventrites III-V shiny, impunctate. Ventrites I and II virtually glabrous, with only isolated, fine short setae; ventrites III-V with setae denser, longer, erect. Ventrites III and IV together longer than V. Legs slender with scattered fine erect setae throughout; femora slightly clavate; tibiae with inner margin straight, apical spurs of hind and middle tibiae minute, oriented parallel to longitudinal axis of tibia. Genitalia. Aedeagus (Figs 29-30) with body short, apodemes long ( 2.5 times length body of aedeagus); lightly sclerotized; lateral margins subparallel to near apex, then convergent to apex, apex very slightly produced; internal sac long, extended to near apex of apodemes, with indistinct patch of minute denticles at about midlength.

Female. Unknown.

* Type material. - Holotype, male, ECUADOR: Cotopaxi: Cotopaxi Natl. Park, Quebrada Mishaguaico, $11,600^{\prime}$, XI-6-88, litter, Herman (AMNH).

\section{Phylogeny and biogeography}

Cladistic methods are those standardly used. Twenty characters were derived from external morphology and genitalia. The data matrix (Table 1) was analyzed using PAUP 3.1.1 (Swofford 1993) employing the Branch and Bound option. All multistate characters were treated as unordered. The closest relatives of Andesianellus appears to be the Andean genera Adioristidius Voss and Macrostyphlus Kirsch, and for the purpose of the analysis conducted here these taxa were chosen as the outgroup. For some characters $(8,11$, $13,17,19,20)$ all states present in species of $A n-$ desianellus occur in various species of Adioristidius or Macrostyphlus. In these situations, that state considered plesiomorphic in Adioristidius or Macrostyphlus is similarly considered plesiomorphic in Andesianellus.

Twenty characters are included in the cladistic analysis of Andesianellus. These characters and their states are the following:

1. Body size. [0], large ( $>3.50 \mathrm{~mm})$; [1], small $(<3.50$ $\mathrm{mm})$.
2. Sculpture of the rostrum-frons interface. [0], punctate; [1], punctate with individual punctures confluent. giving a subrugose appearance; [2], individual punctures indistinct, the area distinctly rugose.

3. Eye shape. [0] transverse; [1] subcircular.

4. Eye size. [0], composed of 10 or more facets; [1], composed of 5-10 facets; [2], composed of 2-4 facets; [3], composed of a single facet.

5. Form of rostrum-frons interface. [0], base of rostrum and frons continuous, rostrum-frons juncture flat; [1], base of rostrum and frons merged at angle, rostrumfrons juncture concave.

6. Rostral dorsal carina. [0] slightly developed; [1] strongly developed.

7. Antennal club shape. [0] oval; [1] inflated.

8. Appressed setae of rostrum-frons and pronotum. [0], setae simple; [1], setae singly or multiply cleft almost to base, appearing plumose.

9. Form of pronotum. [0], transverse, wider than long; [1], subcylindrical, longer than wide.

10. Postocular lobes. [0] slightly developed; [1] absent.

11. Sculpture of pronotum. [0], punctate; [1], punctate, but also with variously developed small tubercles.

12. Dorsal erect setae of pronotum and elytra. [0], simple; [1], clavate.

13. Sculpture of elytra. [0], punctate; [1], punctate but also with variously developed small tubercles, especially laterally near the humerus.

14. Elytral stria 10. [0], continuous to elytral apex; [1], interrupted opposite metacoxa, but continued opposite ventrite II; [2], terminated opposite metacoxa.

15. Basal elytral margin. [0] low and rounded; [1] raised and subcarinate.

16. Size and orientation of middle and hind tibial spurs. [0], spurs moderate, oriented obliquely to the longitudinal axis of the tibia; [1], spurs minute, oriented parallel to the longitudinal axis of the tibia.

17. Apex of aedeagus. [0], not (or only very slightly) produced; [1], markedly produced, acuminate.

18. Sclerotization of aedeagus. [0], heavily sclerotized; [1], lightly sclerotized.

19. Nodulus of spermatheca. [0], swollen; [1], flat.

20. Nodulus of spermatheca, position. [0], subapical; [1], markedly subapical.

Analysis of the data matrix (Table 1) resulted in 12 cladograms with 29 steps, $\mathrm{CI}=0.815$ (excluding uninformative characters) and RI $=0.891$ (Table 2). A strict consensus cladogram (Fig. 56) supports two distinct groupings of species as fol- 
lows: A. masneri, A. hermani, A. microphthalmicus, A. carltoni, A. fulgidus, A. cotopaxi and A. minutus, A. planirostris, A. tricarinatus. This cladogram shows only resolved relationships within the second lineage as follows: (A. minutus, $(A$. planirostris, A. tricarinatus)). Relationships within the first lineage are totally unresolved indicating present uncertainty about all species relationships.

From a biogeographic perspective, the species of Andesianellus from Peru form a monophyletic group, which is sister to another monophyletic (although presently unresolved) group comprising the species from Colombia and Ecuador. Such a general progression pattern is shared with most other Andean Rhytirrhinini. For example, of the eight known species in the genus Acrorius, the three from Colombia and northern Ecuador form a monophyletic group sister to a monophyletic group composed of the remaining five species from southern Ecuador and southern Peru (Morrone 1994a). Similarly, of the ten known species of Macrostyphlus, the nine from northern Ecuador, Colombia and Venezuela are grouped together, and sister to this lineage is the single species from Peru (Morrone 1994c). In the genus Nacodius, with four known species, the two Peruvian species comprise a monophyletic lineage, sister to a paraphyletic group comprised of the two remaining species from Ecuador (Morrone 1994b). Other Andean Rhytirrhinini such as Adioristidius and Amathynetoides are found only from Peru south into Bolivia and Chile (Morrone 1994c), and Rupanius Morrone from Colombia is monotypic (Morrone 1995).

It is quite evident that Andean representatives of Rhytirrhinini are descended from taxa from the Austral region that colonized the northern Andes in a progressive south to north manner as shown by Van der Hammen (1974) for other organisms.

\section{Acknowledgements}

We would like to thank the curators for permission to examine specimens in their care and for the loan of these specimens. We also thank Anne T. Howden for comments on the manuscript. An Ernst Mayr Grant from the Museum of Comparative Zoology (Harvard University) and a Collections Study Grant from the

Revised manuscript accepted November 1995.
American Museum of Natural History to RSA enabled discovery of many of the specimens used in this study; additional financial support was from a Research Advisory Committee (RAC) Grant at the Canadian Museum of Nature. JJM has been supported by a National Science Foundation Research Fellowship at the American Museum of Natural History. Thanks are also due Chris Carlton (University of Arkansas), Rich Leschen (University of Kansas), Lee Herman (American Museum of Natural History), and Lubomir Masner (Agriculture Canada) for their efforts in collecting specimens in Ecuador and Colombia, and Larry Watrous (formerly of the Field Museum of Natural History) for collecting specimens in Peru. François Génier (CMN) prepared the line drawings and the plates. Lewis Ling, Carleton University prepared the scanning electron micrographs.

\section{References}

Morrone, J. J. 1992. Revision sistemática, análisis cladístico y biogeografía histórica de los géneros Falklandius Enderlein y Lanteriella gen. nov. (Coleoptera: Curculionidae). Acta Entomologia Chilena 17: 157-174.

- 1994a. Systematics of the Andean genus Acrorius Kirsch (Coleoptera: Curculionidae). Coleopterist's Bulletin 49: 101-114.

- 1994b. Clarification of the taxonomic status of species formerly placed in Listroderes Schoenherr (Coleoptera: Curculionidae), with the description of a new genus. American Museum Novitates 3093, 11 pp.

- 1994c. Systematics, cladistics and biogeography of the Andean weevil genera Macrostyphlus, Adioristidius, Puranius, and Amathynetoides, new genus (Coleoptera: Curculionidae). Ibidem 3104, 63 pp.

- 1995. A new genus of Rhytirrhinini from Colombia (Coleoptera: Curculionidae). Caldasia 17 (82-85): 603-606

Morrone, J. J. \& Anderson, R. S. 1995. The Falklandius generic group: Cladistic analysis with description of new taxa (Coleoptera: Curculionidae). American Museum Novitates $3121,14 \mathrm{pp}$.

Morrone, J. J., Diaz, N. B. \& Loiácono, M. S. 1992. Comparative morphology of mouthparts in the tribe Listroderini (Coleoptera: Curculionidae). Elytron 6: 47-59.

Paynter Jr, R. A. \& Traylor Jr, M. A. 1981. Ornithological gazeteer of Colombia. vi +311 pp. Cambridge, MA.

Stephens, L. \& Traylor Jr, M. A. 1983. Ornithological gazeteer of Peru. vi +273 pp. Cambridge, MA.

Swofford, D. L. 1993. PAUP. Phylogenetic analysis using parsimony. Version 3.1.1. Computer program distributed by the Illinois Natural History Survey. Champaign, Illinois.

Van der Hammen, T. 1974. The Pleistocene changes of vegetation and climate in tropical South America. Journal of Biogeography 1: 3-26. 